TITLE: A STUDY OF LIMITER DAMAGE IN A MAGNETIC-FIELD ERROR

KEGION OF THE ZT-4OM EXPERIMENT

authonis: H. Makowitz, * Consultant to CTR-2

*

On ? eave of absence from $\bar{B}_{2}$

National Laboratory at the Institute for Fusion $S t$ istin, Texas

susmitted to. Proceedings of the 3rd Topical Meeting on Fusion Reactor Materials Alburuerque, NM, USA, September 19-22, 1983:

Edited by J.B. Whitley, K.i. Wilson and F.W. Clinard, Jr.

(To be published as a special issue of the Journal of Nuclear Materials)

\title{
DISCLAIMER
}

\begin{abstract}
This report was preparod as an account of work sponsored by an syency of the I'nitod Stotes Gevernment. Neither the United States Government nor any agency thereof, nor any of their employees, makes any warranty, exprea or implied, or anumes any legal liability or responsibility for the eccuracy, completenees, or usefulness of any information, apparatus, product, or preceses disclosed, or represents that its use would not infringe privalely owned rights. Reference herein to any slecific commercial product, procoses, or sorvice by trade name, trademark. manufacturet, or otlerwise does not necesarily constitu'e or imply its endorsement, recommendation, or favoriting by the United States Governmen! of any agency thereor. The views and opinions of authon exprosed herein do not nocosesrily state or reflect those of the i inited States Government or any agency theroed.
\end{abstract}




\section{A STUDY OF LIMITER DAMAGE IN A MAGNETIC FIELD ERROR REGION OF THE ZT-4OM EXPERIMENT}

H. Makowitz*, Consultant to CTR-2

Los Al amos National Laboratory. Los Alamos, New Mexico 87545

A study has been initiated of material plasma interactions on the $2 T-40 M$, Reversed Field Pinch (RFP) plasma physics conifinement experiment at LOS Al amos National Laboratory. Observations of the evaporation and cracking of TiC coatings, Initially placed on an AXF-50 Graphite mushroom limiter, installed in a high field error region (e.g. an experimental vacuum vessel/liner port) were investigated. A parametric study was performed of the thermal and stress behavior of the limiter and coating materials undergoing plasma meterial heat exchange processes, in order to infer the magnitude of heat flux necessary to explain the observed material damage. In addition the vacuum (liner) wall material behavior was studied parametrically using the same heat flux values as the 1 imiter study. A one-dimensional conduction model was used with applied heat and radiation boundary conditions, for predicting temperature distributions in space and time, where the thermal stress was calculated using a restrained in bending only plate model. Wall loadings corresponding to first wall. limiter energy fluxes ranging between $1 \times 10^{2} \mathrm{~W} / \mathrm{cm}^{2}$ and $1 \times 10^{5}$ $\mathrm{W} / \mathrm{cm}^{2}$ were used as parameters with plasma material interaction times $\left(\tau_{00}\right)$ between $0.5 \mathrm{~ms}$ and $10 \mathrm{~ms}$. Short plasma energy deposition time $(\mathrm{r} 0 \mathrm{~g}, 10 \mathrm{~ms})$ spacial and time histories of temperature and stress were calculated for SS-304, Inconel-625, TiC and AXF-50 Graphite materials. The parametric study indicates that for ${ }^{2}-6 \mathrm{~ms}$ a wall loading of $=1 \times 10^{4} \mathrm{~W} / \mathrm{cm}^{2}$ resulis in the melting of Inconel and SS-304 first. wall material and loading of $65: 10^{4} \mathrm{~W} / \mathrm{cm}^{2}$ results in the melting of TiC and Graphite. For :nconel, stresses in excess of the tensile strength occur for $Q_{0}$ greater $1 \times 10^{3} \mathrm{~W} / \mathrm{cm}^{2}$. The same is true for SS-304. For Graphite AXF-50 the tensile strength is exceeded for $0,>1 \times 10^{4} \mathrm{~W} / \mathrm{cm}^{2}$. From the observations of damage and the parametric results calculated it can be inferred that an energy flux of $1 \times 10^{1} \mathrm{~W} / \mathrm{cm}^{2} \leq \eta_{0} \leq$ $5 \times 10^{4} \mathrm{~W} / \mathrm{cm}^{2}$ was observed over a time scale of $5 \mathrm{~ms} \leq 90 \leq 10 \mathrm{~ms}$ in the field error region. if the model considsiect is relevant to the phenomenon in question.

\section{D!SCUSSION}

A parametric study was performed using the TASsl computer code. This code was developed for system study purposes, and hence due to its general nature was not optimized for the problem presently leing analyzed. The physics model used consisted of a flat plate exposed to a heat flux $Q_{0}$ for time $t$, with radiation bouriflary conditions for both surfaces, to $T_{w}$ and $T_{w_{2}}$ she surface temperatures of the inner and outer walls relative to the Iimiter/first wall surface. The baslc equation, Eq. (1). Is formilated in dimensionless form, [q. (2), and subject to stabllity and convergence criterion, Eq. (3). The boundary conditions,
Eqs. (4) and (5), are formulated in dimensioniess form. Eq. (8) and Eq. (9). The thermal stress model used, Eq. (10), is solved using simpson's rule, Eq. (11), for a given temperature distribution at time $t$.

Convergence and stability analysis, for low power cases, Indicated that for long time $(\sim 10 \mathrm{~s})$ cases a time step of $0.2 \mathrm{~ms}$ and a spacial mesh size of 15 nodes/iinear $\mathrm{cm}$ were sufficient. Finer mesh and smaller time steps were used where necessary for short times is $10 \mathrm{~ms})$. In general, an icuracy of $\leq 0-156$ is expected. For wall loadings in excess of 1. $10^{4} \mathrm{~W} / \mathrm{cm}^{2}$. smaller $\Delta x$ and $\Delta t$ values were used when necessary.

On leave of absence from Biookhaven National Laboratory at the Institite for fusion Studles. Austin, Texas. 
$K \frac{\partial^{2} T}{\partial x^{2}}-\frac{\partial T}{\partial t}=\frac{S_{0}}{\partial C_{p}} e^{-\gamma x_{p}(t)}$.

(1)

If

$$
\begin{aligned}
& k=\frac{k}{\partial C_{p}}, \\
& T=k t / l^{2} \quad(r>0), \\
& x=x / 2 \quad(0<x<1), \\
& 0=2^{2} / K\left(T_{1}-T_{0}\right) . \\
& \dot{a}=S_{0}(t) \exp (-r L x) .
\end{aligned}
$$

If

1. Spaciai Mode Position.

$n$ - Time step.

$$
\theta=\left(T-T_{0}\right) /\left(T^{1}-T_{0}\right) \text {. }
$$$$
0_{1, n+1}+201-1, n+(1-2 \lambda) \theta_{1, n}
$$$$
+\Delta 10 \dot{n}_{1, n}+\lambda \theta_{1+1, n} \text {. }
$$

$1+1$ or $M+1, n * 0$, and where $\lambda=$ si $/(\Delta x)^{2}$.

$\lambda \leq \frac{1}{6} \cdot>$ A stable and Converged Solution . 13

At $x=0$

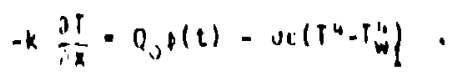

At $x=1$,

$$
-k \frac{\partial T}{\partial x}=\sigma E\left(T^{4}-T_{W_{2}}^{4}\right) \quad
$$

Then

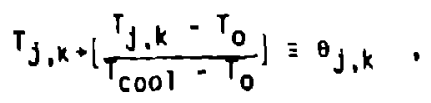

and

$$
\left[T_{(00)} \cdot T_{1}\right] \cdot
$$

Then for Eq. (4)

$$
\theta_{1, n}=\theta_{1+1, n}+\frac{\Delta x \theta_{0} \theta\left(L^{2}, / K\right)}{k\left[T_{c o 0}-T_{0}\right)} .
$$

or

$$
\begin{aligned}
& \theta_{1, n}=0_{1+1, n} \\
& +\left[\frac{\Delta x}{k}\right]-\left[0_{0} p\left(2^{2}, / K\right)=00\left(1 y_{, n-1}-T_{r_{1}}^{y_{1}}\right)\right]
\end{aligned}
$$

ond for Eq. (5)

$$
\begin{aligned}
& \theta_{1+1, n}=01, n
\end{aligned}
$$

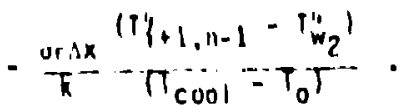


Thermal stress madel plate restrained in bending only:

$$
\begin{aligned}
& \sigma_{y y}=o_{z z}=\frac{a E}{\Gamma-v} \mid-T \\
& \left.+\frac{1}{2 l} \int_{0}^{l} T(x, t) d x\right] .
\end{aligned}
$$

where $E \equiv$ Youngs Modulus (PSI),

a $\equiv$ Coeff. of Thermal Expansion $\left({ }^{\circ} \mathrm{c}-1\right)$,

$$
v \equiv \text { Poisson's Ratio. }
$$

Calculated using Simpson's rule:

$$
\begin{aligned}
& \int_{0}^{l} T(x) d x=\frac{\Delta x}{3}[T(1) \\
& +4 \underset{\text { odd }}{[} T(M)+2 \underset{\text { even }}{i} T(M)+T(M+1)] .
\end{aligned}
$$

2. PARAMETTIC STUDY RESULTS SUMMMARY

The parameter scudy was carried out for a Whle range of $U_{0}$ values, between $1 * 10^{2} \mathrm{~W} / \mathrm{cm}^{2}$ and $1 \times 10^{5} \mathrm{H} / \mathrm{cm}^{2}$. A summary of short time $1 \mathrm{c}$ $10 \mathrm{~ms}$ ) results is presiled in Fig. I. It can be scen from the flgure that a wall loading of

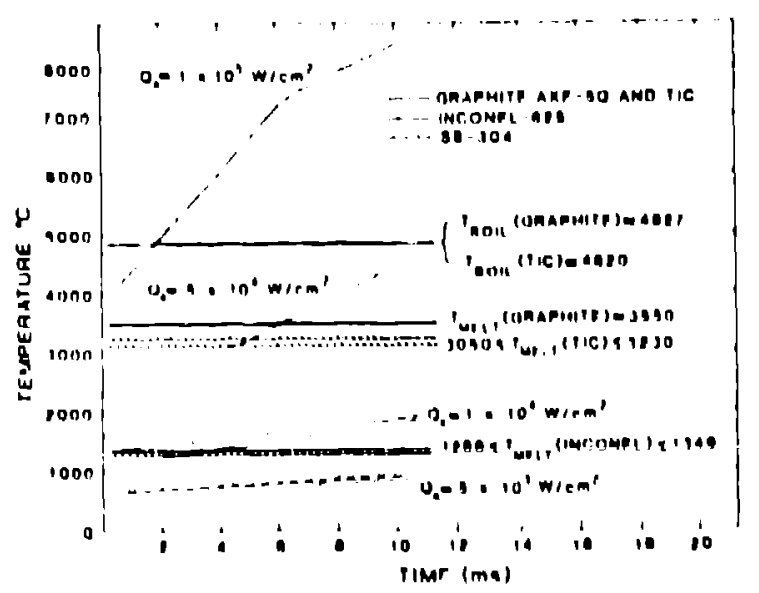

FI GURE: I

Temperature versus time behavior.
- $1 \times 10^{4} \mathrm{~W} / \mathrm{cm}^{2}$ results in melting of Inconel and SS first wall materlal and loading of $=5$ $\times 10^{4} \mathrm{~W} / \mathrm{cm}^{2}$ result in melting of TiC ind Graphlte. Themal material properties are summarized on Tables I through IV.

TABLE 1. INCONEL-625

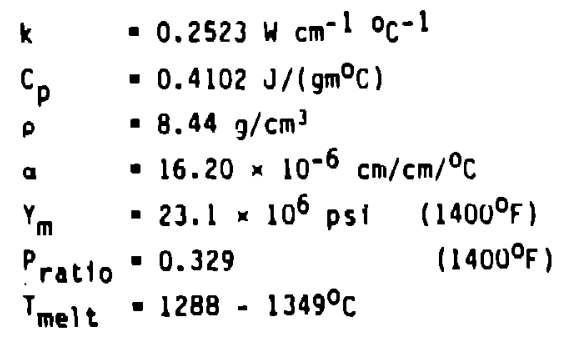

TABLE 11. SS-304

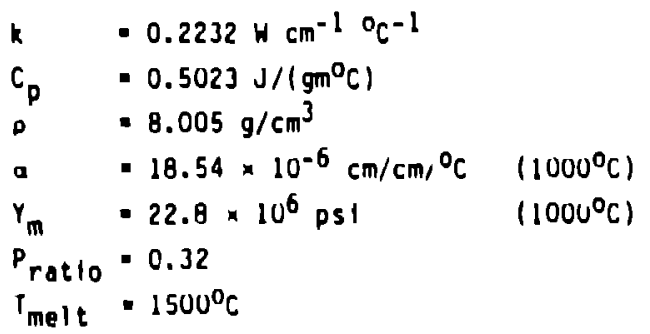

TAOLE 111. GRAPIIITE AXF-50

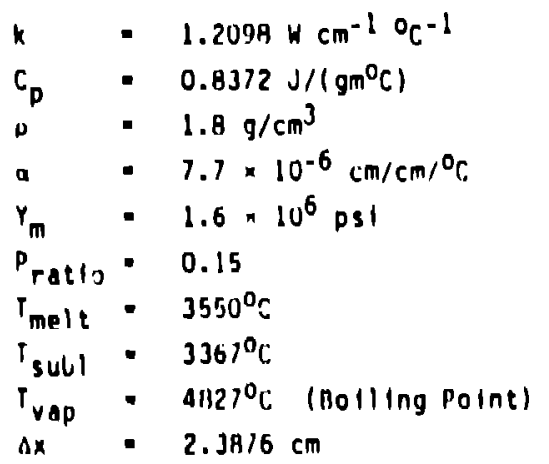

ax(Thermocouple) $-0.3175 \mathrm{~cm}$ 
TABLE IV. TIC PROPERTIES

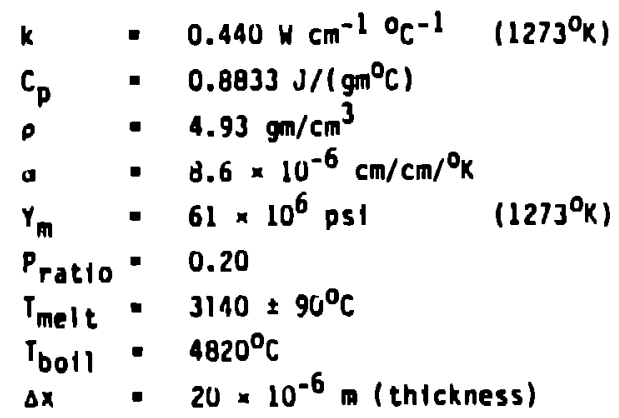

Thermal stress analysis for Inconel, 5S-304, Graphlte, and TIC was performed as a function of $Q_{0}$ for $10 \mathrm{~ms}$ and $1 \mathrm{~ms}$ energy deposition times. Table $v$ lists the relevant stress fallure parameters for the materials of interest, where avallable. For Inconel-625, stresses in excess of the tensile strength occur for $O_{0}$ greater than $21 \times 10^{3} \mathrm{~W} / \mathrm{cm}^{2}$. The same is true for 55-304. For Graphite AXF -50. the tensile strength is exceeded for approxtinately a $O_{0}$ of $>1 \times 10^{4} \mathrm{H} / \mathrm{cm}^{2}$.

3. PIIYSICAL OBSERVATIDNS AND CONCLUSION

A IIC coated AXF-5Q Graphlte mushroom Imiter, Installed in a high fleld error region (a.g., an experimental vacuum vessel/liner portl, was examined during and ofter a number of 2T-4uM dlscharges, by both real time filming (camera) and direct physical inspection. The danage, Fig. 2, can best be characterlzed as evaporation and cracking (see eniargement. Fig. 3) of the TiC coating. The relevant $2 T-40 M$ discharge and machine parameters are listed in Table VI.

Fron the observations of damage and the parametric results calculated it can be Inferred that an energy flux of $1 \times 10^{4} \mathrm{H} / \mathrm{cm}^{2}$ < $\theta_{0}<5 \times 10^{4} \mathrm{H} / \mathrm{cm}^{2}$ was observed uver a time scale of $5 \mathrm{~ms} \times \tau_{a_{0}}<10 \mathrm{~ms}$ in the fleld error region. If the model considered is relevant to the phenomenon in question.

\section{REFERENCE}

1. J. A. Flllo, u. Majumdar, and H. Makowitz, "Thermal And S. ress Studies (TASS)," BNL26057 (Maŕch 1919 ).

TADLE VI. 2T-4OM PARMILTEISS

GRAPHITE MUSIIROOM LIMITER TESTS

$\begin{array}{ll}\text { Minor plasma radius } & 0.2 \mathrm{~m} \\ \text { Mijor plasma radius } & 1.14 \mathrm{~m} \\ \text { Toroldal current } & 120-180 \mathrm{kA} \\ \text { Current Pulse Duration } & 5-7 \mathrm{~ms} \\ \text { Fill Pressure } & 2.0 \mathrm{mTorr} \\ T_{0} \text { (on axis) } & -300 \mathrm{eV} \\ \bar{n}_{\text {e }} & -1.5 \times 10^{19} \mathrm{~m}^{-3}\end{array}$

tadle V. StREsS material parameters

\begin{tabular}{|c|c|c|c|c|}
\hline & S5-304 & Inconel-625 & IIC & Graphlte AXF -50 \\
\hline Yleld Strength & $22,000 \mathrm{psl}$ & $42-110 \mathrm{ks} \mid$ & $\ldots$. & $\ldots$. \\
\hline UItImate Tonsile Strength & $56,000 \mathrm{ps1}$ & -... & $280 \mathrm{MH} / \mathrm{m}^{2}$ & $\ldots-\ldots$ \\
\hline Compressive Strength & ..... & $\ldots$ & $875 \mathrm{mH} / \mathrm{m}^{2}$ & 19,000 ps1 \\
\hline Floxural strength & $\ldots$ & -.... & -..-- & $12,000 \mathrm{ps} 1$ \\
\hline Tenslle Strength & $\ldots$ & $120-160 \mathrm{ks} 1$ & & $8.000 \mathrm{psl}$ \\
\hline Tensile Strain to Fatlure & -.... & ......- & -... & 0.82 \\
\hline
\end{tabular}



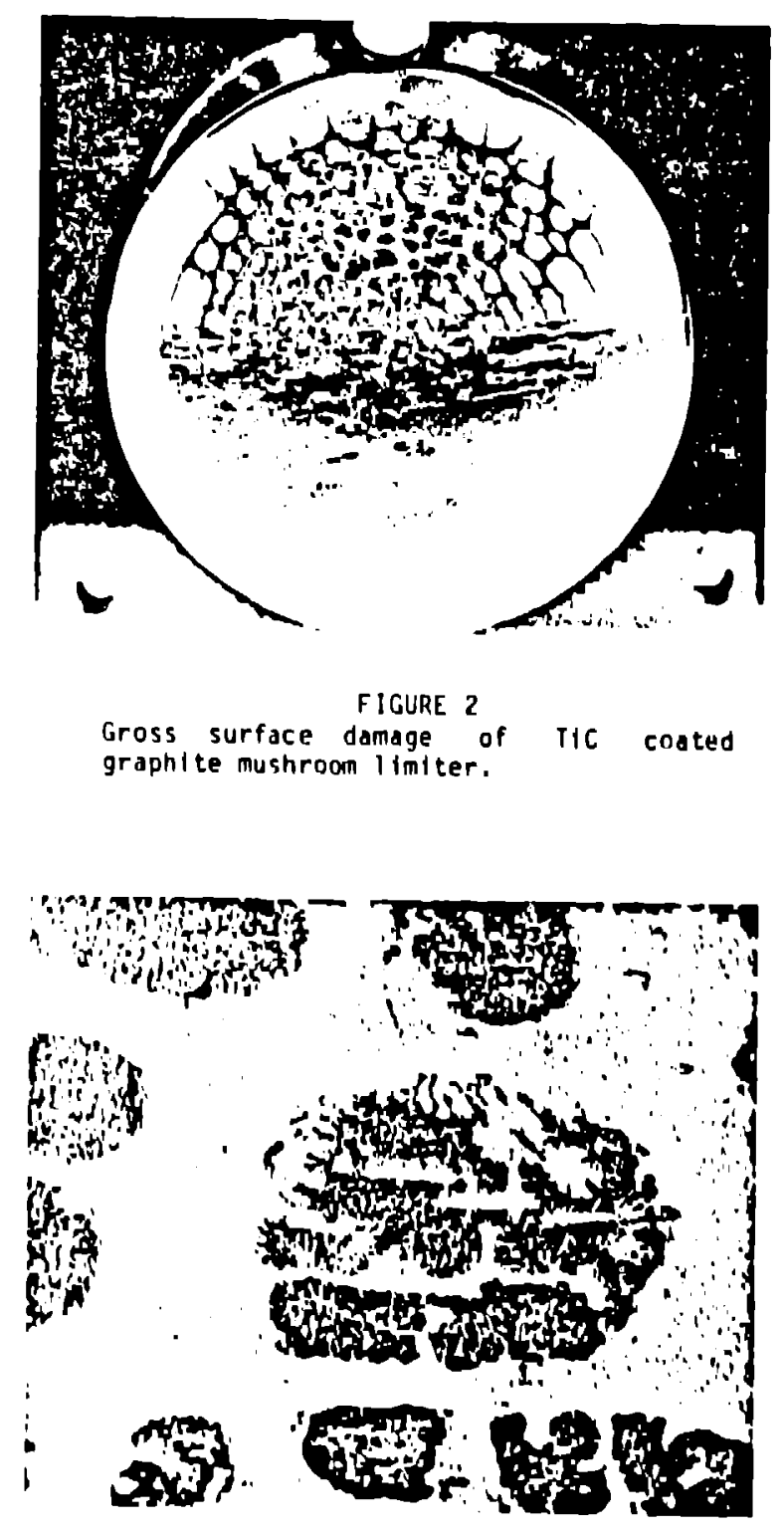

Flillukt $]$

Close-up of IImiter damage. Hic surfice cracking is shown. 